\title{
Public Transit in the Social Marketing Framework
}

\author{
Devajyoti Deka \\ University of Southern California
}

\begin{abstract}
In view of the recent successes of social marketing in the various areas within the public, nonprofit sector, this study considers public transit as a socially marketable concept. The study contends that although service marketing is also important for the transit industry, there is a greater need for emphasizing the social marketing of transit. It is argued that social marketing of transit will have to deviate from the conventional service marketing approach in the key areas of market identification and segmentation, communication, distribution, and consideration of price.
\end{abstract}

\section{Introduction}

The purpose of this study is to show that the social marketing approach can be a useful mechanism for reviving the deteriorating public transit market. Although current transit service marketing practices utilize some aspects of the social marketing approach, public transit is now essentially marketed as a service rather than a socially desirable concept. Based or this assertion, the study considers public transit in the framework of social marketing, or concept marketing approach, and provides some recommendations for the future. It is ex- 
pected that the arguments in this article will provide the basis for further research, especially empirical investigations regarding potential benefits from the social marketing of transit.

It is argued that public transit deserves a certain amount of voluntarism from the general population due to its significant welfare and environmental missions, which can be obtained by the social marketing approach. The fact that transit is predominantly in the public sector makes a still stronger case in favor of its social marketing since this marketing approach emerged in the public, nonprofit sector.

The study claims that social marketing of transit will have to deviate from the conventional transit service marketing in the key areas of market identification and segmentation, communication, and distribution. In addition, there is a need to realize that the notion of price in social marketing has a different connotation than in transit service marketing.

The study recommends that social marketing of transit should be simultaneously carried out with transit's service marketing, for the two approaches address significantly different targets and follow different strategies. Since service marketing is already popular with transit agencies, the study addresses the social marketing of transit almost exclusively. Social marketing of transit will have to address larger and nontraditional audiences. While the transit service marketing approach has conventionally focused on the transit users, the social marketing approach will have to address the affluent or elite, the educated, and the socially concerned sections of the society. Appeals to women and children are also likely to have significant consequences on the transit market. Because of the large audience addressed, it becomes imperative that the marketing efforts identify precise market segments within these sections of the population.

In regards to communication of the marketing concept, the study emphasizes the importance of emotional and moral messages. It recommends that the concept marketing of transit should utilize the mass media, advocacy and pressure groups, and interpersonal channels of distribution in a sequential manner. Due to the important role of advocacy and pressure groups, the study envisions 
an active involvement of politicians in the social marketing of transit. Finally, it is emphasized that the high price of a modal shift from the automobile to transit, in terms of time, efforts, lifestyle, and psyche of the target adopters, may require somewhat upgraded and differentiated transit service than is currently available.

\section{The Social Marketing Approach}

Kotler and Roberto equate social marketing with social change campaigns and define such campaigns as "an organized effort conducted by one group (the change agent), which intends to persuade others (the target adopters) to accept, modify, or abandon certain ideas, attitudes, practices, and behavior."' In recent times, Andreasen has provided two similar definitions of social marketing. According to him, "Social marketing is the adaptation of commercial marketing technologies to the analysis, planning, execution and evaluation of programs designed to influence the behavior of target audiences in order to improve their physical and mental well-being and/or that of the society of which they are a part." In a more recent literature, Andreasen defines social marketing as the "adaptation of commercial marketing technologies to programs designed to influence the voluntary behavior of target audiences to improve their personal welfare and that of the society as a whole." ${ }^{\prime 3}$ Andreasen maintains that the essential quality of social marketing is that it aims at changing the behavior of the target adopters. He further cautions that educational or awareness generation programs should not be equated with social marketing since such programs do not necessarily aim at behavior change.

Social marketing evolved for marketing concepts rather than products or services. Although the cited definitions of social marketing do not specify whether a product or a service can qualify for social marketing, in social marketing literature, the term is essentially used to describe the marketing of concepts rather than products or services. This study, therefore, uses the terms "social marketing" and "concept marketing" as synonymous.

It has not been long since social marketing emerged as a discipline, and yet its popularity is increasing rather rapidly. In fact, due to the increasing importance of marketing concepts or ideas, the definition of marketing has undergone 
a significant change. In 1985, for example, the American Marketing Association changed its definition of marketing to include ideas with products and services. ${ }^{4}$

\section{Successes in Social Marketing}

The areas where social marketing seems to have made the most ground are environment and health, especially in anti-smoking, safe sex, recycling, and blood donation campaigns. Safe sex campaigns among homosexual populations and anti-smoking campaigns have been some of the most apparent successes in social marketing. ${ }^{5}$ The increasing consciousness about environmental degradation has also added to the popularity of social marketing, as is apparent from the recycling movement. The increase in the recycling of aluminum beverage cans almost quadrupled in this country between 1972 and $1989,{ }^{6}$ indicating the effectiveness of the recycling campaign. The increase in recycling of cans is found to be significant irrespective of deposit payment requirements. ${ }^{7}$ This is a clear indication that a large part of the success in recycling is due to voluntarism. While recycling of glass has shown an even greater rate of increase in the last decade, ${ }^{8}$ a significant promise is evident in the case of paper, plastic, steel cans, and motor oil.

Similar to the recycling campaign, social campaigns have also proved to be an important contributor to voluntary blood donation. ${ }^{9}$ The successes of marketing in the campaigns for anti-smoking, safe sex, recycling, and voluntary blood donation indicate that social marketing may have applicability in many other areas of social concern, including public transit.

Although the popularity of concept marketing is increasing in recent years, it does not ensure that all socially marketed concepts will be equally successful in changing behavior of the target adopters. In anti-smoking and safe sex campaigns, the benefits from the behavior change are accrued directly to the individual participant, while in recycling and voluntary blood donation, the beneficiary is the society as a whole. Concepts that directly benefit an individual are readily perceptible by the target adopters, but not the concepts having benefits for the entire society. Campaigns such as recycling and blood donation, in the 
absence of perceptible direct return to the targets, need a significant amount of voluntarism from the general population.

Since the affluent or elite and the educated populations are in a relatively favorable position to understand environmental and social problems, they are the populations that recycling and blood donation campaigns appeal. Public transit as a social concept is similar to recycling and blood donation campaigns, for its social benefits accrue to the society rather than the transit user.

\section{Transit as a Social Concept}

It is noted from Andreasen's definition in an earlier section that an essential objective of the social marketing approach is the well-being of the target audience and the society as a whole. According to this definition, the welfare and the environmental missions of public transit certainly qualify it for social marketing. Some of the principal socially desirable benefits from transit arise from reductions of roadway congestion, fuel consumption, and air pollution and creation of substantial job opportunities. ${ }^{10}$ Moreover, transit provides services to those who cannot afford more expensive modes of travel, to the physically disabled, and to the elderly. These benefits of public transit accrue not only to the transit users but to the society as a whole. An increase in the popularity of public transit is, therefore, desirable for the general population. The basic objective of social marketing for public transit will be to convey this message to the society.

\section{The Social Marketing Process}

A marketing process normally involves analysis related to product differentiation, product life-cycles, market segmentation, price, communication, and distribution. In the context of social marketing of transit, market identification, market segmentation, price, communication, and distribution have particular importance, for this marketing approach differs from the service marketing approach in regards to these components.

Market segmentation is the partitioning of consumers on the basis of some criteria so that marketing can focus on a particular group. Market segmentation is said to have four levels: mass market, segmented markets, micromarkets, and 
individual markets, where degrees of segmentation increase from the mass market to the individual markets. "I

Price in commercial marketing includes the likes of list price, discounts, allowances, payments, credits, etc. ${ }^{12}$ In social marketing, however, price could be both monetary or non-monetary. Four types of non-monetary prices have been identified as important in social marketing: time, effort, lifestyle, and psyche. ${ }^{13}$

Communication is the process by which a message is transmitted from the change agent to the target adopters. The objective of communication is to generate awareness, interest, and desire and, subsequently, to bring forth a change of behavior of the target adopters. The communicated message could be rational, emotional, or moral. ${ }^{14}$ Rational messages show how the marketed object will be beneficial to the target adopters in terms of price, quality, or functionality of a marketed object. Emotional messages are meant to invoke sentiments and thereby instill some positive or negative feelings so that a behavior change would occur. The Bay Area Rapid Transit (BART) successfully used a well-known comedian for promotional purposes, showing that humor can also be an effective means of emotional communication..$^{15}$ Finally, moral messages can also be communicated for social marketing purposes. Conservation of fossil fuel for the future generations is an example of moral messages.

The intermediaries in the distribution of social marketing can be classified as the mass media, the interpersonal channels, and the advocacy and pressure groups. The various channels have different impacts on the behavior of the target adopters. Their use may be simultaneous, depending on the purpose of the marketing effort.

The mass media, comprising printed matter, radio, and television, is the most effective channel for rapid and extensive dissemination of the marketed concept. The media is effective primarily in generating awareness and interest among the target adopters, but not in changing their behavior.

Interpersonal channels are another method of information dissemination from the change agents to the target adopters, by means of a two-way conversation between the parties. This method of distribution is highly effective in changing behavior of the targets. 
Advocacy and pressure groups constitute another kind of intermediary in the marketing of concepts. In terms of effectiveness in changing behavior of the target populations and the expense of communication, advocacy and pressures groups are located between the mass media and the interpersonal channels. Advocacy groups adopt a top down approach in advising the population, while pressure groups adopt a bottom up approach to pressurize the government for social change. In the context of public transit marketing, for example, advocacy groups would advice the target adopters to use transit as the popular mode, while pressure groups would demand a better service from the transit agencies.

\section{The Marketing Challenge to Public Transit}

Public transit's share of passenger trips has been decreasing substantially over the years. Transit's share of person trips in the year 1977 was 2.4 percent, which declined to 2.0 percent by $1990 .^{16}$ Transit's share of commuting trips also shows a similar decline, as the proportion of the trips reduced from 12.6 percent in 1960 to 6.2 percent in $1980 .{ }^{17}$ This substantial decrease is evident in almost all the metropolitan areas of the country. The loss of transit passengers in the last few years is evident among all the traditional user groups, namely, the racial minorities, women, senior citizens, and the low-income populations. Loss is also evident for almost all trip purposes,$^{18}$ showing the seriousness of the problem.

Transit's market started deteriorating back in the 1920s. The decline was most visible a few years after the World War II. ${ }^{19}$ The 1950 s and the 1960 s experienced substantial construction of freeways and a tremendous growth in suburban home-building. The association of transit's decline during this period with the growth of suburbia and the extensive construction of freeways can be inferred from the fact that almost 200 transit agencies went out of business between 1954 and 1963, leaving many medium-sized cities without transit service. ${ }^{20}$

With the increasing suburbanization of high income households, transit services were extended to the suburbs in spite of a relatively high cost of service provision in these areas. Wachs attributes this expansion of transit services to the concerns of taxpayers about transit subsidization. ${ }^{21}$ However, in the absence of 
serious marketing efforts, and for various other reasons, the provision of transit services has not led to an increasing popularity of transit among the suburban populations.

The situation facing public transit cannot be called a happy state. Aside from the problem of losing ridership, there are threats from government to reduce subsidies. Reactions to public transit's failure have often been severe, and scholars have developed cases for privatization or deregulation of transit.2 ${ }^{22}$ There is also a concern about subsidies because of the feeling among some sections that taxpayers' money is being wasted on a futile bid.

The passenger trips lost by transit have invariably been added to the automobile, as the latter is the only mode that has significantly gained in the share of metropolitan travel. In other words, the marketing challenge to public transit comes from the popularity of the automobile. This challenge to transit from automobile is substantial, for the automobile is not only a status symbol, but it also provides "independence, mobility, comfort and privacy that people will not easily give up." ${ }^{23}$ The marketing of cars, car parts, accessories, gasoline, and even commercial banking has significantly contributed to the increasing popularity of the automobile. Due to the tremendous challenge from the automobile and related industries, transit marketing needs substantial augmentation.

\section{Limitations of Current Transit Service Marketing Practice}

Although transit can be viewed both as a service and a concept, available transit marketing literature essentially treats it as a service. The emphasis on service marketing of transit is clear from this assertion of the National Cooperative Transit Research \& Development Program: "The major marketing characteristics usually considered are the four "P"s: product, place, price, and promotion. In transit use, product and place are usually represented by service."${ }^{.24}$ Similar arguments are found in other transit marketing literature also, as apparent from this statement: "In the context of urban transportation, a services marketing approach is appropriate because many urban travel modes could be characterized more as a service than a product...." ${ }^{25}$ And yet again, "Public transportation is a consumer product where product and place are related to the service and 
price is related to the fare." ${ }^{.26}$ All these postulations do not seem to consider that service marketing emerged outside the public and nonprofit sectors, and hence its applicability to public transit is limited. Most of the available service marketing literature, including the American Management Association's Handbook of Marketing for the Service Industries, excludes public transit altogether. ${ }^{27}$ Since transit marketing is to be conducted in the public sector and it has to appeal to social sentiments, the concept marketing of transit is at least as relevant as its service marketing.

Dunbar and Lovelock maintain that transit management became professional and sophisticated in regards to marketing in the 1970s. ${ }^{28}$ Significant efforts were made during the 1960s and the 1970s to revive the transit market, and the industry received a major boost from federal funding. ${ }^{29}$ The marketing effort during that period was a part of the general efforts to revive the transit industry. Although transit marketing techniques may have substantially improved in the 1970s, the term "social marketing," as it is understood today, cannot be used to describe the marketing practices of that time. The social marketing approach received wide acceptance only in the $1980 \mathrm{~s},{ }^{30}$ and its application continues to spread to various disciplines even today.

One cannot deny, however, that the service marketing of transit has adopted some components of the social marketing approach. It is, for example, not too uncommon to come across transit promotional campaigns referring to pollution and congestion. Yet, the processes of marketing services and concepts are significantly different. Moreover, in areas like transit, where voluntarism is an important requirement, social marketing is a still more favorable approach than service marketing.

The service marketing of transit relies on the traditional assumption that the important considerations for a public transportation system are unit costs, input of resources, relative distribution of costs, provision of service, and collection of revenues. ${ }^{31}$ From the users' point of view, the considerations are said to be cost of travel, convenience and comfort, reliability, safety, and security. ${ }^{32}$ While these are certainly important considerations from the viewpoint of the transit providers 
and users, one cannot afford to ignore the significant welfare and environmental missions of transit.

A significant work has already been done that evaluates the current state of transit marketing. Research by Smith, Razzouk, and Richardson, ${ }^{33}$ which included information from 85 bus transit agencies in different parts of the country, showed that only about half of the agencies had separate marketing departments. According to another survey, conducted by the American Public Transit Association in 1988, about 60 percent of the transit agencies had separate marketing departments. ${ }^{34}$ The work of Smith et al. shows that current marketing research of the agencies focuses only on the current users. The mass media seems to be the only distribution channel used in the transit marketing efforts. Market segmentation was found to be poor. While transit marketing experts have gone to the extent of suggesting that potential car purchasers can be an exclusive market segment, ${ }^{35}$ current transit marketing practices have failed to capture even broad categories such as gender and social class.

From the review of current transit service marketing practices, a few ideas emerge about their limitations and the prospects for the future. First of all, transit marketing has so far concentrated mainly on the typical user classes. The second critical limitation of transit service marketing has been in detailed segmentation of the market based on demography, geography, class, culture, income, race, reference group, etc.

The third limitation of current transit service marketing is the absence of adequate service differentiation. Differentiation of public transit implies a diversified set of services that fulfills the travel needs of the various target segments. The differentiation perspective suggests a shift of emphasis towards a more demand-responsive service than that provided by the current fixed-route, fixedschedule systems. However, demand-responsive services, when attempted, have turned out to be highly expensive, and vehicle productivity has been found to be much lower than anticipated. ${ }^{36} \mathrm{~A}$ relatively low emphasis on demand-responsive services by transit providers is evident from the fact that such services accounted for less than one percent of the total transit trips in the country in 1993. ${ }^{37}$ Based on the experience with demand-responsive transit so far, one can question the 
extent to which service-differentiated marketing can possibly be adopted by transit agencies under the current circumstances of decreasing revenue.

The fourth limitation of transit service marketing has emerged from the overemphasis on monetary costs of travel as a component of price. As Rothschild mentions, the involvement of nonmonetary costs makes the marketing of nonbusiness goods and services more difficult than the marketing of business goods and services. ${ }^{38} \mathrm{~A}$ realistic evaluation of the price involved in a mode shift from automobile to transit has to include not only monetary considerations, but also the inconvenience, the slow speed, and the psychic costs of using transit. These considerations are not common for transit service marketing and, whenever these considerations have been made, transit agencies have adopted, knowingly or unknowingly, certain components of the social marketing approach.

Finally, a serious limitation of current transit service marketing is observed in terms of distribution or channeling. The distribution channel that appears to be the most dominant in current transit service marketing is the mass media, which is not as effective a mechanism for bringing about a behavior change as some of the other channels. According to a 1988 survey of public transit agencies by the American Public Transit Association, news releases and radio advertisements were the most frequently used distribution channels. ${ }^{39}$ In contrast, efforts to reach out the target adopters by distribution channels such as direct mail, customer service centers, and information kiosks were far less common. In the light of Andreasen's definition of social marketing, where behavior change of the target is the basic objective, the current distribution efforts by transit agencies seem ineffective.

\section{The Requirements for Social Marketing of Transit}

The fundamental objective of social marketing of transit will be to convey the important message to the targets that transit has significant benefits to the society. It has to be clearly emphasized that transit is a solution to many social problems, including reduction of air pollution and traffic congestion. It also needs to be conveyed that by serving the poor, the disabled, and the elderly, public transit has been significantly contributing to the welfare of the society. 
Another important objective of the social marketing approach to transit will be to improve transit's image. Since transit currently carries a substantial amount of minority and low-income passengers, in society's outlook the current transit riders may be the weaker sections. This may be one of the reasons for the reluctance of the general population to use transit.

The metropolitan societies in the United States have diverse populations, where certain sections are more privileged than the others in terms of opportunities and choices. Metropolitan societies are diverse not in regards to income and affordability alone, but also due to cultural, ethnic, and racial variations. In a diverse society, the sections with fewer opportunities and choices have a tendency to emulate the more privileged sections. The increase in automobile trips among minorities in the recent years is very likely the result of this tendency. Engel and Blackwell have provided an example of minority behavior by noting that certain immigrant minority populations are unwilling to use promotional coupons for purchases since such transactions seem to denigrate them. ${ }^{40}$ For the same population, the use of public transit most likely has an identical or similar meaning as promotional coupons; if they are still using transit, it is not because of the appeal but the sheer necessity. It can be inferred from such minority behavior that the onus to improve public transit's image is on the general population rather than the current riders of transit.

The goals of social marketing can be identical or similar to the goals of service marketing. In the case of public transit, although minor objectives may vary from agency to agency, because of almost a national concern about transit's deteriorating market, increasing ridership is a primary objective for most agencies. Both service marketing and social marketing can be useful for achieving this objective. For achieving the same objective, however, the two approaches will exhibit differences in the marketing process, namely, in the selection of target adopters, in market segmentation, in determination of the components of price, in the selection of messages for communication, and in the selection of distribution channels.

Marketing transit as a social concept will require emphasis in certain respects that are ignored by transit service marketing. The first such consideration 
is about the size of the target adopters. While current transit service marketing mainly focuses on a small segment of the society-namely, the users-transit's social marketing will have to address a larger population, possibly segments covering the entire society.

The larger audience also requires that the market segments be more precise. Market segmentation will need to consider the importance of reference groups in making decisions by the target. In the case of blood donation campaigns, for example, it has been clearly shown that the influence of friends and family is significant on the commitment of the target donors. ${ }^{41}$ The influence of social norms on individual behavior has also been shown to be very distinct in another blood donation study, ${ }^{42}$ indicating clearly the importance of reference groups in the social marketing approach.

The most important target segments for social marketing of transit would be the affluent or elite and the educated, for these groups can afford to be more concerned about the society and the environment than any other sections of the population. Similar to recycling and blood donation campaigns, social marketing of transit will require a significant amount of voluntarism, which can be expected more from the socially aware populations than the rest. Targeting the elite population will be especially important because it serves as the ideal for the other populations.

For social marketing of transit, the younger age groups appear to be another promising market segment. The success of anti-smoking campaigns among school children shows that targeting the young population in their formative ages has significant positive consequences. Learning at younger ages has important influence on a person's lifetime habit formation. ${ }^{43}$ Moreover, beneficial social changes depend to a large extent on the education and socialization of children. ${ }^{44}$ As evident from occasional programs to familiarize children with transit operations, ${ }^{45}$ the importance of targeting children as potential users is not unknown in transit marketing. Yet a full-scale effort in this direction has always been absent.

Due to a greater voluntarism among women for social causes, it may be appropriate for social marketing of transit to appeal to this section of the population with particular emphasis. Research has shown that a significantly higher 
proportion of women donates blood in the voluntary procurement drives than in the market-based procurement efforts. ${ }^{46}$ This special quality in women has been attributed to their nurturing role and altruistic nature. Since the social marketing of transit will have to depend to a great extent on the altruism of the population, the role of women in popularizing transit could be important.

Women's transit use in the last few years has been decreasing at a faster rate than men's, and scholars have attributed this rapid decline in women's transit use to changes in their employment status, access to an automobile, and so on. ${ }^{47}$ Other scholars maintain that the likelihood of forming chained trips is higher for women than for men, ${ }^{48}$ and the increasing need to make chained trips may have contributed to the decline in their transit trips. The effects of increasing women's participation in the work force, their increasing access to the automobile, and the need to make complex trips provide a challenge to the transit industry in retaining this broad market segment. The use of social marketing appears to be one of the ways that can help retaining this traditional market segment of transit.

The communication of the concept to the target adopters will have to be mainly emotional and moral. Although rational communications about price, quality, and functionality are significant from the perspective of transit service marketing, they are less significant in the social marketing of transit because of its appeal to voluntarism for a social cause. Emotional messages can be highly effective on young targets. Generating fear can be one of the most effective emotional communications, as has been explicitly exhibited in the case of the antismoking and safe sex campaigns. Such communications can be directed in transit marketing against the competing automobile mode, portraying messages of damage to the environment by the automobile, or of lives lost in automobile accidents.

Moral communication will have no less significance than emotional messages in the social marketing of transit. The appeal towards a better environment, which would be an avenue for social marketing of transit, has a serious moral connotation. Although predominantly used by religious and charitable organizations, moral messages have found their rightful place in the environmental campaigns, thereby indicating that such messages can be extremely useful for transit as well. 
Transit agencies so far have almost exclusively relied on the mass media for distribution or channeling of their services. For marketing the transit concept, however, transit agencies will have to look beyond the media, as its effectiveness does not go much beyond generating awareness and interest among the target adopters.

Nonprofit organizations, transit lobbies, local politicians, community leaders, environmental groups, and local businesses can significantly contribute to the social marketing of transit. Social marketing was popularized mainly in the areas of health and environment, where advocacy and pressure groups play a dominant role. Their role will also be important in marketing the transit concept. While the mass media will be able to generate awareness and interest about the concept among large sections of the citizenry, the role of advocacy and pressure groups will be important for effecting the actual behavior change at the level of communities.

Although it may currently appear almost impossible to form advocacy and pressure groups to popularize transit in the suburban areas, where transit is currently least popular, once the mass media effectively performs its tasks of generating awareness and interest, formation of such groups may be relatively simple. The role of politicians in advocacy and pressure groups is extremely important. In neighboring Canada, for example, the role of politicians in matters related to transit advocacy is substantial, where public transit provides a significant platform for the election of mayors. ${ }^{49}$ Similar efforts by politicians in the U.S. may be somewhat less probable, yet their increasing involvement is possible if the mass media can generate the required amount of awareness in the initial period of the marketing drives.

Interpersonal communication, or personal contact, is a familiar term in transit service marketing, ${ }^{50}$ although its merit seems to be substantially greater in the context of transit concept marketing. Interpersonal distribution of the transit concept will depend not only on initiation by the mass media but also on the success of the advocacy and pressure groups. Its importance, therefore, will increase in the later stages of the marketing campaigns. 


\section{Conclusion}

Discussions in this paper have shown that, currently, transit is considered essentially in the domain of service marketing, while there is ample scope to consider it as a concept for social marketing. The nature of transit, especially due to its environmental and welfare missions, qualifies it as a socially desirable concept.

The current transit marketing practices, by accepting the service marketing approach, have failed in terms of market identification, segmentation, price, communication, and distribution. The analysis of transit in the social marketing framework suggests the importance of appealing to the upper social classes comprised of the affluent or elite and the educated, as well as women and children. In terms of communication of the marketing messages, emotional and moral messages seem appropriate for this purpose. For the distribution of the concept, the mass media should take the initiative to generate awareness and interest among the targets, so that advocacy and pressure groups, and subsequently interpersonal channels, can take over. The study envisions a greater political involvement in transit due to the emphasis of social marketing on advocacy and pressure groups.

As the social marketing of transit would need to target sections of the population that are quite different from those traditionally targeted by transit service marketing, it will be appropriate to continue the two approaches simultaneously. The distinctions between the two approaches in terms of price, communication, and distribution also support simultaneity of the efforts.

It must not be expected, however, that a shift from automobile to transit will be achieved with little effort, for the change will be a high-involvement decision for the targets due to the high prices in terms of time, efforts, lifestyle, and psyche. The effectiveness of the social marketing approach will certainly be higher in attracting the general population if simultaneous efforts are made towards improving the quality of transit services.

\section{Notes}

1 Philip Kotler and Eduardo L. Roberto, Social Marketing: Strategies for Changing Public Behavior (New York: The Free Press, 1989), 6. 
2 Alan R. Andreasen, "A Social Marketing Research Agenda for Consumer Behavior Researchers," Advances in Consumer Research 20 (1993): 1.

3 Alan R. Andreasen, "Social Marketing: its Definition and Domain," Journal of.Public Policy \& Marketing 13 (1994): 110.

4 Seymour H. Fine, "Introduction to Social Marketing," in Social Marketing: Promoting the Causes of Public and Nonprofit Agencies, ed. Seymour H. Fine (Boston: Allyn and Bacon, 1990), 1.

5 D. Wayne Taylor and Thomas E. Muller, "Eco-Literacy and Environmental Citizenship: a Social Marketing Challenge for Public Sector Management," Optimum 23 (Winter 1992): 7.

6 Nyles V. Reinfeld, Community Recycling: System Design to Management (Englewood Cliffs, NJ: Prentice Hall, 1992), 14.

7 Ibid., 12.

$8 \quad$ Ibid., 36

9 Ernie S. Lightman, "Women and Voluntary Blood Donation," Journal of Sociology \& Social Welfare 9 (December 1992): 619.

10 George M. Smerk, The Federal Role in Urban Mass Transportation (Bloomington: Indiana University Press, 1991), 3.

"Philip Kotler, "From Mass Marketing to Mass Customization," Planning Review 17 (September/October 1989): 11.

12 Philip Kotler, Principles of Marketing (Englewood Cliffs, NJ: Prentice-Hall, 1983), 44.

13 Seymour H. Fine, The Marketing of Ideas and Social Issues (New York: Praeger Publishers, 1981), 84.

14 Philip Kotler and Alan R. Andreasen, Strategic Marketing for Nonprofit Organizations (Englewood Cliffs, NJ: Prentice-Hall, 1987), 512.

is Judy McCusker, "How BART Won Riders Back," Railway Age 190 (March 1989): 45.

16 Alan E. Pisarski, Travel Behaviors Issues in the 90's (Falls Church, Virginia: US Department of Transportation, Federal Highway Administration, 1992), 17.

17 Alan E. Pisarski, Commuting in America (Westport, CT: Eno Foundation for Transportation, 1987), 48.

18 Pisarski, 1992, 19.

19 David W. Jones, Jr., Urban Transit Policy: An Economic and Political History (Englewood Cliffs, NJ: Prentice-Hall Inc., 1985), 15. 
20 Martin Wachs, "U.S. Transit Subsidy Policy: In Need of Reform," Science 244 (June 1989): 1545.

21 Ibid., 1547.

22 Peter Gordon, Myths and Facts of Nation's Transit Policy (Los Angeles: Reason Foundation, 1991), 16.

23 Michelle Frumkin-Rosengaus, Increasing Transit Ridership through a Targeted Transit Marketing Approach (Berkeley: University of California, Dissertation Series, 1987), 2. National Cooperative Transit Research \& Development, Transit Marketing: Successes and Failures (Washington, D.C.: Transportation Research Board, 1987), 1.

P. B. Everett and L. K. Ozanne, "Marketing Theory and Urban Transportation Policy," Transportation Research Record No. 1402 (1993), 52.

Frumkin-Rosengaus, 13.

Carole A. Congram, ed., The AMA Handbook of Marketing for the Service Industries (New York: AMACOM, 1991). The only article on transportation in this Handbook essentially focuses on airline and freight, without any mention of urban transit services. See chapter by Craig E. Cina, "Transportation," 455-468.

Frederick C. Dunbar and Christopher H. Lovelock, "The State of the Art in Urban Travel Consumer Research," in Marketing Public Transportation: Policies, Strategies and Research Needs for the 1980's, ed. Richard K. Robinson and Christopher H. Lovelock (Washington, D.C.: American Marketing Association, 1981 ), 87.

Christopher H. Lovelock and others, Marketing Public Transit: A Strategic Approach (New York: Praeger Publishers, 1987), 5. Fine, 1990, 1.

See, for example, Anthony R. Tomazinis, Productivity, Efficiency and Quality in Urban Transportation Systems (Lexington: Lexington Books, 1975), 60. Ibid., 66. Mary F. Smith, Nabil Y. Razzouk and Scott A. Richardson, "The Role of Marketing in Mass Transit: An Empirical Investigation," Transportation Journal 30 (Fall 1990).

${ }^{34}$ Estimated from American Public Transit Association, 1988 Survey of Transit Marketing Methods and Marketing Expenditures (Washington, D.C.: American Public Transit Association, 1988), Table 4A. Lovelock and others, 12.

Roger F. Teal and others. Shared-Ride Taxi Services as Community Public Transit (Irvine: University of California, Irvine, 1980), 6. 
Estimated from American Public Transit Association, 1996 Transit Fact Book(Washington, D.C.: Statistics and Information Systems Division, American Public Transit Association, 1996), Table 5.

Michael L. Rothschild, "Marketing Communications in Nonbusiness Situations: or Why It's So Hard to Sell Brotherhood Like Soap," in Public and Nonprofit Marketing: Cases and Readings, ed. Christopher H. Lovelock and Charles B. Weinberg (New York: John Wiley \& Sons, 1984), 58.

39 American Public Transit Association, 1988, Table 2A.

40 James F. Engel and Roger D. Blackwell, Consumer Behavior, 4th ed. (Chicago: Dryden Press, 1982), 80.

41 Randy P. McCombie, "Blood Donation Patterns of Undergraduate Students: Family and Friendship Correlates," Journal of Community Psychology 19 (April 1991): 162.

42 Jane A. Piliavin and Donald Libby, "Personal Norms, Perceived Social Norms, and Blood Donation," Humboldt Journal of Social Relations 13 (Fall/Winter \& Spring/ Summer, 1985/1986): 192.

43 Lewis P. Lipsitt, "The Future of Training in Human Infant Development," in Child Behavior and Development: Training for Diversity, ed. Joan H. Cantor, Charles C. Spiker and Lewis P. Lipsitt (Norwood, NJ: Ablex Publishing Corporation, 1991), 278.

44 Sheldon H. White. "Graduate Training in the Fourth Establishment: Tradition and Change in the Study of Human Development," in Child Behavior and Development: Training for Diversity, ed. Joan H. Cantor, Charles C. Spiker and Lewis P. Lipsitt (Norwood, NJ: Ablex Publishing Corporation, 1991), 177.

45 Noel A. Smith, "The State of Marketing in Mass Transit," Metro Magazine 84 (MayJune 1988): 52.

46 Lightman, 616.

47 Pisarski, 1992, 25.

48 James G. Strathman, Kenneth J. Dueker, and Judy S. Davis, "Effects of Household Structure and Selected Travel Characteristics on Trip Chaining," Transportation 21 (1994): 34-35.

49 Lovelock and others, 7.

so See, for example, National Cooperative Transit Research \& Development, 2. 


\section{References}

American Public Transit Association. 1996. 1996 Transit Fact Book. Washington, DC:

Statistics and Information Systems Division, American Public Transit Association. American Public Transit Association. 1988. 1988 Survey of Transit Marketing Methods and Marketing Expenditures. Washington, DC: American Public Transit Association, 1988.

Andreasen, A. R. 1993. A Social Marketing Research Agenda for Consumer Behavior Researchers. Advances in Consumer Research 20: 1-5.

Andreasen, A. R. 1994. Social Marketing: its Definition and Domain. Journal of Public Policy \& Marketing 13: 108-114.

Congram, C. A., ed. 1991. The AMA Handbook of Marketing for the Service Industries.

New York: AMACOM.

Dunbar, F. C., and C. H. Lovelock. 1981. The State of the Art in Urban Travel Consumer

Research. In Marketing Public Transportation: Policies, Strategies and Research Needs for the 1980's, ed. Richard K. Robinson and Christopher H. Lovelock. Washington, DC: American Marketing Association.

Engel, J. F., and R. D. Blackwell. 1982. Consumer Behavior. 4th ed. Chicago: Dryden Press.

Everett, P. B., and L. K. Ozanne. 1993. Marketing Theory and Urban Transportation Policy. Transportation Research Record No. 1402: 51-56.

Fine, S. H. 1990. Introduction to Social Marketing. In Social Marketing: Promoting the

Causes of Public and Nonprofit Agencies, ed. Seymour H. Fine. Boston: Allyn and Bacon.

Fine, S. H. 1981. The Marketing of Ideas and Social Issues. New York: Praeger Publishers. Frumkin-Rosengaus, M. 1987. Increasing Transit Ridership through a Targeted Transit Marketing Approach. Berkeley: University of California, Dissertation Series.

Gordon, P. 1991. Myths and Facts of Nation's Transit Policy. Los Angeles: Reason Foundation.

Jones, D. W., Jr. 1985. Urban Transit Policy: An Economic and Political History. Englewood Cliffs, NJ: Prentice-Hall Inc.

Kotler, P., and A. R. Andreasen. 1987. Strategic Marketing for Nonprofit Organizations. Englewood Cliffs, NJ: Prentice-Hall.

Kotler, P., and E. L. Roberto. 1989. Social Marketing: Strategies for Changing Public Behavior. New York: The Free Press. 
Kotler, P. 1989. From Mass Marketing to Mass Customization. Planning Review 17 (September/October): 10-13+.

Kotler, P. 1983. Principles of Marketing. Englewood Cliffs, NJ: Prentice-Hall.

Lightman, E. S. 1992. Women and Voluntary Blood Donation. Journal of Sociology \& Social Welfare 9 (December): 613-625.

Lipsitt, L. P. 1991. The Future of Training in Human Infant Development. In Child Behavior and Development: Training for Diversity, ed. J. H. Cantor, C. C. Spiker, and L. P. Lipsitt. Norwood, NJ: Ablex Publishing Corporation.

Lovelock, C. H., and others. 1987. Marketing Public Transit: A Strategic Approach. New York: Praeger Publishers.

McCombie, R. P. 1991. Blood Donation Patterns of Undergraduate Students: Family and Friendship Correlates. Journal of Community Psychology 19 (April): 161-165.

McCusker, J. 1989. How BART Won Riders Back. Railway Age 190 (March): 45-47.

National Cooperative Transit Research \& Development. 1987. Transit Marketing: Successes and Failures. Washington, D.C.: Transportation Research Board.

Piliavin, J. A., and D. Libby. 1985/86. Personal Norms, Perceived Social Norms, and Blood Donation. Humboldt Journal of Social Relations 13 (Fall/Winter \& Spring/ Summer): 159-194.

Pisarski, A. E. 1987. Commuting in America. Westport,CT: Eno Foundation for Transportation.

Pisarski, A. E. 1992. Travel Behaviors Issues in the 90's. Falls Church, VA: U.S. Department of Transportation, Federal Highway Administration.

Reinfeld, N. V. 1992. Community Recycling: System Design to Management. Englewood Cliffs, NJ: Prentice Hall.

Rothschild, M. L. 1984. Marketing Communications in Nonbusiness Situations: or Why It's So Hard to Sell Brotherhood Like Soap. In Public and Nonprofit Marketing: Cases and Readings, ed. C. H. Lovelock and C. B. Weinberg. New York: John Wiley $\&$ Sons.

Smerk, G. S. 1991. The Federal Role in Urban Mass Transportation. Bloomington: Indiana University Press.

Smith, M. F., N. Y. Razzouk, and S. A. Richardon. 1990. The Role of Marketing in Mass Transit: An Empirical Investigation. Transportation Journal 30 (Fall): 30-35.

Smith, N. A. 1988. The State of Marketing in Mass Transit. Metro Magazine 84 (MayJune): 52-58. 
Strathman, J. G., K. J. Dueker, and J. S. Davis. 1994. Effects of Household Structure and Selected Travel Characteristics on Trip Chaining. Transportation 21: 23-45.

Taylor, D. W., and T. E. Muller. 1992. Eco-Literacy and Environmental Citizenship: A Social Marketing Challenge for Public Sector Management. Optimum 23 (Winter): 616.Teal, R. F., and others. 1980. Shared-Ride Toxi Services as Community Public Transit. Irvine: University of California, Irvine.

Tomazinis, A. R. 1975. Productivity, Efficiency and Quality in Urban Transportation Systems. Lexington: Lexington Books.

Wachs, Martin. 1989. U.S. Transit Subsidy Policy: In Need of Reform. Science 244 (June): 1545-1549.

White, S. H. 1991. Graduate.Training in the Fourth Establishment: Tradition and Change in the Study of Human Development. In Child Behavior and Development: Training for Diversity, ed. J. H. Cantor, C. C. Spiker, and L. P. Lipsitt. Norwood, NJ: Ablex Publishing Corporation.

\section{About the Author}

DevajYotı Deka is a doctoral student at the School of Urban Planning and Development, University of Southern California. 